\title{
Teopoética do traste em Manoel de Barros
}

\author{
Eli Brandão da Silva ${ }^{1}$ \\ Huerto Eleuterio Pereira Lima ${ }^{2}$
}

\begin{abstract}
Resumo: Este artigo apresenta uma leitura teopoética da obra do poeta Manoel de Barros, analisando e interpretando sua poesia como (re) criação teológica. Parte-se do pressuposto que seus poemas configuram num só tecido complexas relações entre literatura e religião, poesia e teologia, poesia e sagrado. A compreensão é a de que na poesia de Manoel de Barros o sagrado está associado às "coisas jogadas fora por motivo de traste", ao rés do chão e que as coisas ordinárias do cotidiano, bem como pessoas excluídas, são expressões por meio das quais a divindade é nomeada e se manifesta. Trata-se de uma singular poesia que tece um dizer poético cujo olhar se volta para as coisas humílimas, monumenta o pequeno, sacraliza o chão e conjuga experiência poética com experiência religiosa. A interpretação de figuras e temas referentes às relações entre o humano e o sagrado na obra do poeta é operada por meio de uma hermenêutica interdiscursiva, que se apoia em saberes teológicos e literários. Neste empreendimento teopoético foram úteis as contribuições de Pagán (2011), Paz (2012; 2013), Magalhães (2013), Fiorin(1999), Maingueneau (2007), dentre outros.
\end{abstract}

Palavras-chave: Poesia. Teologia. Manoel de Barros.

\section{Considerações iniciais}

No contexto geral dos estudos envolvendo as relações entre literatura e religião, o termo teopoética tem sido utilizado por diferentes pesquisadores, a partir de diferentes perspectivas e em diferentes acepções. Neste artigo, nós o utilizamos para denominar, por um lado, a obra de Manoel de Barros como configuração de uma singular poética teológica e, por outro, nosso específico empreendimento analítico e interpretativo dos poemas do autor, por meio de uma espécie de hermenêutica interdiscursiva.

Nosso pressuposto é o de que tal relação entre poesia e teologia tem suas origens no seio de antigas narrativas míticas, onde o que hoje chamamos de literatura se confunde com o que primeiramente se chamou na Grécia e ainda se pode chamar de teologia.

Sendo a tradição judaico-cristã um matiz constituinte da identidade ocidental, torna-se impossível desconsiderar sua influência sobre a produção artística, e dentro desta, a literatura. Entretanto, para, além disso, consideramos que esse profícuo diálogo se estende e inclui relações com outras diferentes tradições religiosas. Num empreendimento hermenêutico como esse não se tem em vista apenas a mera busca de traços dessas tradições religiosas na

\footnotetext{
${ }^{1}$ Doutor pela Universidade Metodista de São Paulo (UMESP). Professor do Departamento de Letras e Artes da Universidade Estadual da Paraíba (UEPB), Campina Grande, PB, Brasil. E-mail: elibrandao.uepb@gmail.com

${ }^{2}$ Doutorando em Literatura e Interculturalidade Universidade Estadual da Paraíba (UEPB), Campina Grande, PB, Brasil. E-mail: huertoluna@yahoo.com.br
} 
literatura, mas busca-se, sobretudo, compreender a literatura como intérprete crítica dessas referidas tradições, como reescritora de seus textos fundantes e forjadora de novas cosmovisões religiosas. Neste sentido, Pagán em seus estudos sobre as relações entre literatura e teologia na América Latina, chamou a atenção para a riqueza da literatura como uma das fontes mais expressivas de conteúdos teológicos e apontou a necessidade de maior exploração dos seus textos:

El diálogo entre La teología y la literatura en América Latina se hace urgente por los obvios interesses que ambas tienen en la memoria mítica y las ensoñaciones utópicas de los pueblos al margen de la modernidad occidental. (...) En un momento en que nuevas corrientes intelectuales tienden a difuminar las fronteras rígidas entre las distintas esferas de la cultura y a subrayarlos aportes epistemológicos y hermenéuticos válidos que provienen del que hacer literario, la relativa ausencia de diálogo entre la teología y la literatura latinoamericana constituye un déficit teórico (PAGÁN, 2011, p. $119,130)$.

Neste nosso cenário brasileiro, destacamos a produção poética de Manoel de Barros, pelo seu intenso e constante diálogo com a teologia, a partir do qual novas e inusitadas imagens do sagrado são produzidas, por meio de uma recriação feita e em diálogo e tensão com discursos da tradição judaico-cristã.

Seu poema Teologia do traste, publicado originalmente no livro Poemas rupestres (2004), cujo paratexto ostensivo indica e fundamenta a conjectura e empreendimento deste trabalho, materializa em sua configuração uma complexa e plurissignificativa relação entre poesia e teologia:

As coisas jogadas fora por motivo de traste são alvo da minha estima.

Prediletamente latas.

Latas são pessoas léxicas pobres porém concretas.

Se você jogar na terra uma lata por motivo de traste: mendigos, cozinheiras ou poetas podem pegar.

Por isso eu acho as latas mais suficientes, por exemplo, do que as idéias.

Porque as idéias, sendo objetos concebidos pelo espírito, elas são abstratas.

E, se você jogar um objeto abstrato na terra por motivo de traste, ninguém quer pegar.

Por isso eu acho as latas mais suficientes.

A gente pega uma lata, enche de areia e sai 
puxando pelas ruas moda um caminhão de areia.

$\mathrm{E}$ as idéias, por ser um objeto abstrato concebido

pelo espírito, não dá para encher de areia.

Por isso eu acho a lata mais suficiente.

Idéias são a luz do espírito - a gente sabe.

Há idéias luminosas - a gente sabe.

Mas elas inventaram a bomba atômica, a bomba

atômica, a bomba atôm.

Agora

eu queria que os vermes iluminassem.

Que os trastes iluminassem.

(BARROS, 2010, p. 438)

$\mathrm{O}$ aspecto teológico do poema, já manifestado pelo seu título: Teologia do traste, nos direciona para um ponto que nos sugere preliminarmente a conjectura de que na enunciação lírica manoelina estão confundidos o fazer poético e fazer teológico. Neste ponto, poesia e teologia se situam num espaço limítrofe onde quase não são identificáveis as diferenças entre uma e outra, visto estarem as mesmas misturadas por meio de tecido metafórico, que tem o sagrado e o teológico como possibilidade de sentido e referência.

É intrigante e instigante, ao mesmo tempo, a adjetivação deste dizer teológico, pelo fato da mesma ser apresentada designar a teologia como produzida a partir do "traste". Isto porque o poeta elege não o que é sublime, mas o que é ínfimo como matéria e conteúdo da preocupação teológica: "Agora eu queria que os versos iluminassem/ Que os trastes iluminassem”. Há uma substancial diferença e peculiaridade entre os elementos escolhidos na obra de Manoel de Barros e a grande parte da produção literária, que, comumente, ao tratar do sagrado em suas obras, utiliza-se de imagens do que é tipicamente tido como sagrado, ou seja, as praticas religiosas oficiais, os símbolos, os oficiais, as coisas sublimes, conceitos e imagens do deus cultuado pela tradição, ao contrário do que encontramos nos poemas de Manoel de Barros, que prefere "as coisas jogadas fora por motivo de traste", metaforicamente figuradas em seu poema pelos “mendigos, cozinheiras e poetas".

Ao eleger os marginalizados como elementos constitutivos de sua teopoética, o poema traz à tona uma dimensão social fraturada e, ao mesmo, tempo um grito existencial pelo sentido da vida que foi dinamitado (a imagem da bomba atômica metaforiza essa questão) pelo racionalismo da modernidade, pelas ideias que são a "luz do espírito", mas que criaram também a bomba atômica. Como a literatura capta e expressa de forma metafórica os dilemas existenciais do humano, manifesta-se também na literatura não apenas o grito revelador do 
desespero e das angústias humanas, mas também, ao mesmo tempo, uma espécie de suspiro em busca de sentido renovado para a existência. Neste sentido, a literatura revela-se irmanada com a teologia, pelo fato de ambas expressarem em seus textos a permanente busca de respostas às questões existenciais, às questões últimas do humano, aspecto este considerado que, segundo Pagán, pode se constituir ponto de partida para o aprofundamento do diálogo entre literatura e teologia:

\footnotetext{
Esa aporía, personal y social a la misma vez, ese maridaje entre el enigma de la existencia, la angustia de la libertad y el anhelo de descifrar lo que quizá es, en última instancia, inefable e inasible conceptualmente, constituye el punto de partida fascinante de un diálogo posible entre la literatura y la teología (PAGÁN, 2011, p. 131).
}

Sendo grito existencial, a literatura insere em sua materialidade textual o desejo do homem de decifrar o enigma de sua existência diante das múltiplas e angustiantes possibilidades de ser em que está lançado. Além disso, por sua natureza metafórica, intertextual e interdiscursiva, a literatura assimila textos das tradições religiosas envolvidas em suas condições de produção, o que gera um diálogo também com estes referidos textos teológicos e possibilita a reescritura dos mesmos e a criação de novas teologias. E, neste caso, perspectivando estes dois polos, um existencial e outro intertextual e interdiscursivo, nossa teopoética nos possibilita um duplo viés hermenêutico: uma leitura da teologia pelos valores literários nela contidos, e uma leitura da literatura pelos valores teológicos nela contidos. Aqui não se trata de fazer do texto literário mero pretexto para afirmações teológicas, mas sim de buscar interpretar dialogicamente as imagens produzidas pela literatura, tendo por pressuposto que novas teologias podem ser engendradas de forma plausível pelos leitores, estes presos à materialidade da configuração textual, colhendo seus sentidos da plurissignificação metafórica que não pede licença à oficialidade das instituições religiosas.

\section{Teopoética do traste em diálogo interdiscursivo}

Na obra poética de Manoel de Barros percebe-se em muitos dos seus poemas uma relação interdiscursiva com "textos sagrados" da tradição judaico-cristã, deixando entrever reescrituras poéticas que reelaboram e ressignificam o texto bíblico. 
No poema VII do Livro das ignorãnças (1993), vemos que o autor reelabora o texto do Evangelho de João, potencializando novas e singulares configurações e significações:

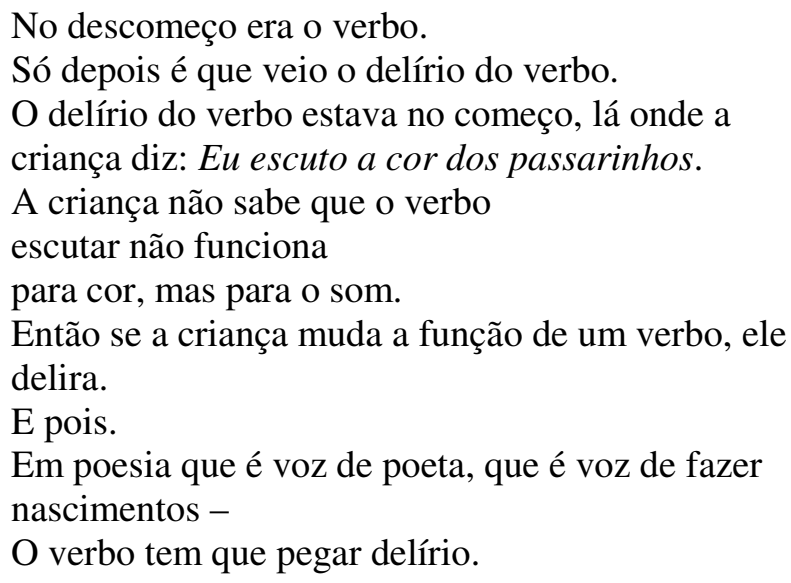
(BARROS, 2010, p. 301)

No poema percebemos o estabelecimento de uma relação intertextual e interdiscursiva com os escritos joaninos (Cap. 1, v. 1-4), por meio da qual percebemos ecos da musicalidade e a reescritura de frases do texto do evangelho, numa clara alusão e estilização que acentuam o tom parodístico, processo que produz efeitos não apenas de ressignificação do texto bíblico, mas de criação de um novo prólogo para o evangelho. Trata-se de um mecanismo intertextual, reconhecível a materialidade do texto evangélico citado quase literalmente nos versos do poema, num claro espelhamento da arquitetura sintática e vocabular: "No descomeço era o verbo" que recria a tão conhecida versão bíblica: "No princípio era o verbo". A intertextualidade pode ser entendida como "o processo de incorporação de um texto no outro, seja para reproduzir o sentido incorporado, seja para transformá-lo" (FIORIN, 1999, p. 30). A incorporação de outros textos se dá através em diferentes níveis de intertextualidade, que são: a citação, alusão e a estilização. Cada processo se realiza de maneira particular num determinado texto; a citação estaria para a presença literal do outro texto, podendo alterar ou confirmar o sentido do texto citado; a alusão se estabelece no plano da reprodução de estruturas sintáticas em que figuras do texto primário são parodiadas; e por último a estilização que compreende em se apropriar de um estilo e/ou procedimentos discursivos de outrem. 
No poema, o texto evangélico é diluído dentro do corpo poético através de uma intertextualidade alusiva, quase que literal, principalmente no verso de abertura, mudando do texto evangélico original apenas a expressão "começo" para "descomeço", o que, mesmo reproduzindo o texto bíblico, o desconstrói e o ressignifica totalmente. A questão central do poema é comungar a ideia de verbo divino e afirmar que o poético reside no mesmo lugar, ou melhor, é como se disséssemos: no princípio era o verbo e o verbo se fez poesia. O principio da linguagem é a poesia, como se o poético fosse o fundamento da linguagem: "Em poesia que é voz de poeta - que é voz de fazer nascimentos". A poesia faz nascer e encarnar o verbo no delírio da voz do poeta, que muda a ordem das coisas: "Eu escuto a cor dos passarinhos", instituindo novas possibilidades de existência de si e da linguagem "escutar cor", fundando novos mundos, uma constante gênese.

Necessário é aqui ressaltar que, ao se configurar uma relação intertextual num texto, simultaneamente se estabelece uma relação interdiscursiva. Isto implica dizer que a teologia pode estar diluída em uma obra, não apenas pelo fato de haver menção a textos sagrados, mas também pelo fato de haver referência a tema teológico, pois neste nosso trabalho entendemos teologia como discurso sobre deus, sobre o sagrado ou sobre textos considerados sagrados por diferentes tradições religiosas. Nesse sentido, ao nos referirmos a uma relação intertextual estamos ao mesmo tempo falando de uma relação interdiscursiva. Entretanto "A interdiscursividade não implica a intertextualidade, embora o contrário seja verdadeiro, pois, ao se referir a um texto, um enunciador se refere, também, ao discurso que ele manifesta" (FIORIN, 1999, p. 35). Desse modo, nem todo texto é intertextual, mas é, por sua natureza constitutiva, interdiscursivo. A interdiscursividade acontece quando "se incorporam percursos temáticos e/ou figurativos, temas e/ou figuras de um discurso em outro" (FIORIN, 1999, p. $33)$.

Em seu poema, Um novo Jó, extraído do seu quarto livro de poesias Compêndio pra uso dos pássaros, publicado no ano de 1960, vemos que, mesmo não existindo a intertextualidade, o poema estabelece relação interdiscursiva pelo fato de remeter a conteúdo teológico, por meio de percurso figurativo e temático:

Desfrutando entre bichos

raízes, barro e água

o homem habitava 


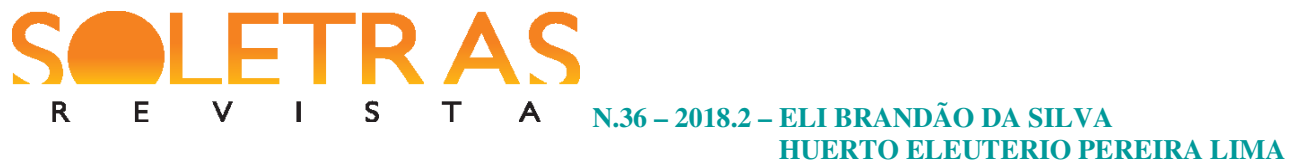

sobre um montão de pedras.

Dentro de sua paisagem

-entre ele a pedra -

crescia um caramujo.

Davam flor os musgos...

Subiam até o lábio

depois comiam toda a boca

como se fosse uma tapera.

Bom era

Sobre um pedregal frio

e limoso dormir!

Ao gume de uma adaga tudo dar.

Não ter nunca chegada

nunca optar por nada.

Ir a terra me recebendo

me agasalhando

me consumindo como um selo

um sapato

como um bule sem boca...

Ir criando azinhavre nos artelhos

a carne enferrujada

desfeita em flor de ave, vocábulos, ícones.

Minha roupa como um reino de traças.

Bom era

ser como o junco

no chão: seco e oco.

Cheio de areia, de formiga e sono.

Ser como pedra na sombra (almoço de musgos)

Ser como fruta na terra, entregue

aos objetos...

(BARROS, 2010, p. 117)

Inicialmente, destacamos que, pela indicação paratextual do título, somos convidados a refletir sobre uma proposta de ser o poema uma reescritura do texto bíblico: "Um novo Jó". Mas, diferentemente do Jó bíblico, que reluta a todo instante contra sua condição de traste, o Jó de Manoel de Barros se sente feliz com o abandono. Veja que o poema opera uma inversão dos valores contidos no texto bíblico. É um novo olhar que o poeta lança sobre a condição de Jó, neste sentido, a literatura não quer justificar o texto original, antes está para desdizê-lo e se 
erige como nova reescritura teológica através da refração literária. Isto porque o Jó manoelino se resigna com sua condição e aceita sua decomposição: "Ir criando azinhavre nos artelhos / a carne enferrujada/ desfeita em flor de ave, vocábulos, ícones./ Minha roupa como um reino de traças", enquanto que o Jó bíblico renega e amaldiçoa a doença e a decadência dada por Deus: “Ainda hoje me queixo e me revolto, porque a mão de Deus agrava meus gemidos" (BÍBLIA, 2013, p. 825).

O interdiscurso está presente como fundamento de toda constituição discursiva, pois a formação de um discurso não se dá isoladamente, ele não é uma realidade que surge do nada, ao contrário, todo discurso é fruto de outras realidades discursivas, por isso "a interdiscursividade (...) é inerente à constituição do discurso" (FIORIN, 1999, p. 35). O poema como discurso é resultado de uma construção que sempre tem em vista outro, pelo fato de que todo e qualquer texto se constrói se apropriando de outros discursos. Não se constituindo como mera colcha de retalhos, mas formando identidade discursiva própria. Isto porque essa relação "consiste em um processo de reconfiguração incessante no qual uma formação discursiva é levada a incorporar elementos pré-construídos, produzidos fora dela, com eles provocando sua redefinição e redirecionamento" (MAINGUENEAU, 1993, p. 113), de modo que o que resulta na obra literária não configura uma mera reprodução de discursos alheios, mas antes uma verdadeira transformação dos mesmos.

No texto manoelino, a relação interdiscursiva acontece no espaço discursivo do poema, onde predominam as trocas enunciativas do campo discursivo da teologia, neste caso o texto bíblico de Jó, espaço discursivo da literatura.

A discussão em torno das interfaces entre literatura e teologia põe em tensão a própria concepção de sagrado e de literatura nos desafia a compreender que o fenômeno do sagrado é anterior e independente da própria religião, que a referência a um símbolo religioso, uma imagem, um "texto sagrado" ou um conceito teológico consagrado por uma tradição religiosa não é condição indispensável para o fazer teológico na literatura. Neste sentido, a reflexão levantada por Magalhães contribui para alargar a compreensão do sagrado na literatura:

Levanto questão sobre outra possibilidade de interface: literatura e sagrado, e faço isso ao retomar, a título de exemplo inicial, a poesia de Hölderlin, que se recusa a pensar o sagrado como algo pertencente somente à religião, pelo contrário, privilegia o sagrado na natureza e no próprio ato poético, no ir e vir da poesia que contribui para que o ser humano retorne ao seu lar, à sua 


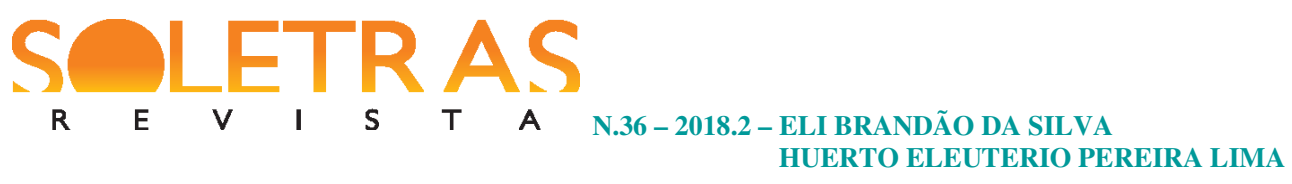

morada, ao mundo (...) O sagrado se torna o elemento fundamental de configuração do ato poético, sendo a religião, assim como apresentei, algo sem importância para a obra de Hölderlin (...) De certa forma, há um retorno ao epifânico na natureza, o sagrado não está dito na tradição, mas se revela na natureza e na poesia. Mas também poderia ser dito que o sagrado está em todas as tradições, por estar na natureza e no ato poético, mas não pertence a nenhuma específica (MAGALHÃES, 2013, p. 6).

Estas considerações de Magalhães contribuem para o aprofundamento dos estudos teopoéticos, ao tempo que possibilitam maior sintonia entre perspectivas de pesquisas desenvolvidas no âmbito dos cursos de Teologia e Ciências da Religião, bem como no âmbito dos cursos de Literatura.

A discussão em torno do sagrado na obra de Manoel de Barros envolve esta referida e ampliada concepção do sagrado, auxiliando na compreensão do transcendente dentro de sua produção poética. Em seu poema Formigas, que faz parte de seu $14^{\circ}$ livro de poesias, Ensaios Fotográficos, publicado no ano 2000, o eu-poético deixa clara essa questão de independência das tradições religiosas:

Não precisei de ler São Paulo, Santo Agostinho,

São Jerônimo, nem são Tomás de Aquino, nem São

Francisco de Assis -

Pra chegar a Deus

Formigas me mostraram Ele.

(Eu tenho doutorado em formigas)

(BARROS, 2010, p. 392)

O poema explicita de forma direta sua independência de toda e qualquer tradição religiosa. A relação com o sagrado não precisou ser mediada pela instituição religiosa, o eu poético consegue chegar a Deus através das formigas. Mais significativo ainda, é o fato de ser negado abertamente a "ajuda" de santos, teólogos e figuras bíblicas para entrar em contato com Deus. O poema é a afirmação veemente de que o sagrado está acima das instituições religiosas, o transcendente está lançado em todas as coisas, inclusive, nas formigas.

O poético, em sua criação, em seu ritmo, em sua matéria - verso, por si mesmo, já é expressão de uma experiência com do sagrado. Ele não precisa da legitimidade da instituição religiosa para se constituir expressão de uma experiência do transcendente. Em sentido análogo, Octavio Paz argumenta em $O$ arco e a lira sobre o tema: 
Poesia e Religião são revelação. Mas a palavra poética não precisa da autoridade divina. A imagem se sustenta sozinha, sem necessidade de recorrer à demonstração racional nem à instância de um poder sobrenatural: é a revelação de si mesmo que o homem faz de si mesmo (PAZ, 2012, p. 144).

Reconhecer e analisar relações intertextuais e interdiscursivas apresenta-se como chave hermenêutica eficaz para o estabelecimento de um diálogo mais coerente entre os campos da teologia e da literatura.

Perspectivar a obra literária como o lugar onde se manifestam e se expressa mas relações dos seres humanos entre si e dos seres humanos com as realidades, ou seja, um objeto aberto, plural, dialógico, ligado ao contexto extraverbal nos coloca diante de um desafio analítico que deve considerar a obra literária como o espaço não só de trocas enunciativas, mas como materialização de experiências humanas, e dentre estas, a experiência do sagrado. Recuperando os versos de Manoel de Barros: "Um girassol se apropriou de Deus: foi em Van Gogh” (BARROS, 2010, p. 301). A arte é a forma humana de tornar Deus presente, encarnado. O ato criador artístico, já é, por sua implicatura de fundação de sentido para comunidade humana, um ato religioso. Religioso porque esse ato me religa a um centro de significação e sentido, não porque ele menciona o nome de Deus ou não.

Para além do tema da recorrência e alusões a textos religiosos, da confissão de fé ou não do poeta, o que, de fato, constitui a poesia como expressão da experiência religiosa é a sua capacidade de revelar o ser do homem, de possibilitar, assim como na experiência religiosa, uma (re) ligação com o sentido último da existência.

O resíduo do sagrado no poético, para além de uma referência a uma tradição religiosa, está na capacidade mesma da poesia operar uma tensão revelatória no ser do homem, que é a descoberta da outridade que lhe habita e o constitui, que antes da experiência poética lhe era desconhecida:

Religião e poesia pretendem realizar de uma vez por todas essa possibilidade de ser que somos e que constitui a nossa maneira própria de ser; ambas são tentativas de abraçar essa "outridade" que Antonio Machado chamava de "essencial heterogeneidade do ser". A experiência poética, como a religiosa, é um salto mortal: uma mudança de natureza que é também uma volta à nossa natureza original. Encoberto pela vida profana ou prosaica, de repente 

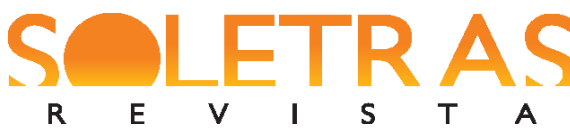

o nosso ser recorda sua identidade perdida; e então aparece, emerge, esse "outro" que nós somos (PAZ, 2012, p. 144).

A poesia, assim como a religião, pretende a transformação do homem, transformação esta que é, ao mesmo tempo, reconhecimento de sua natureza original. Paz coloca o homem em sua capacidade de existência múltipla, o eu não é mais absoluto, o eu é vários, é possibilidade, é inventividade, é encontro com o outro que é aquele, e o outro que somos nós mesmos. Diríamos com ele e para além dele que a poesia é o salto mortal que pode nos angustiar ou nos confortar; pode nos alienar ou nos tirar da alienação cotidiana; pode nos fazer conservadores ou arremessar na eterna novidade que podemos ser, mas sobretudo nos oferece possibilidades de existência, nos tira do cativeiro do determinismo e nos aloca no universo da criatividade.

Observemos o poema de número 11 (o poema não possui um título, apenas a indicação numérica) do Livro sobre nada (1996), os seguintes versos:

A maior riqueza do homem é sua incompletude.

Nesse ponto sou abastado.

Palavras que me aceitam como sou - eu não aceito.

Não aguento ser apenas um sujeito que abre portas, que puxa válvulas, que olha o relógio, que compra pão às 6 horas da tarde, que vai lá fora, que aponta lápis, que vê uva etc. etc.

Perdoai.

Mas eu preciso ser Outros.

Eu penso renovar o homem renovando borboletas.

(BARROS, 2010, p. 374)

O verso inaugural do poema já evoca o reconhecimento da condição de inacabamento do homem: "A maior riqueza do homem é sua incompletude", o que já traz a consciência de que o homem não é absoluto em si mesmo, o outro lhe constitui. A negação da palavra que não provoca a quebra e a ruptura com aquilo que é determinado para o homem ser é suprimida, a palavra poética, aquela que não aceita o determinado, mas que provoca o homem a ser outro é eleita: "Palavras que me aceitam como sou - eu não aceito". O poema acaba com aquele movimento visto por Paz de que a poesia nos desvela aquilo que está encoberto pela vida cotidiana: "Não aguento ser apenas um sujeito que abre portas". O eu poético elenca ao 
longo dos versos finais um série de ações que sintetizam os afazeres cotidianos que acabam tornando o homem apenas um ser que realiza ações pré-determinadas e organizadas pela rotina, ele "precisa ser Outros". O "salto mortal" que a poesia faz o homem dar acontece no poema quando o eu poético afirma seu desejo: "Eu penso renovar o homem usando borboletas", a negação do estabelecido se dá ao se operar nestes versos uma inversão operada pela metáfora da lógica causal das coisas, ou seja, de renovar o homem por aquilo que o senso-comum enxerga como improvável e só a poesia torna possível: a renovação pelas borboletas.

O poema explicita o quanto a poesia de Manoel de Barros tem de inovadora nas relações com o sagrado e a teologia. Entendemos que, para além do significativo diálogo intertextual e interdiscursivo estabelecido com a tradição judaico-cristã na obra de Manoel de Barros, ressalta-se em seus poemas um fato que contamina toda sua poética, a saber, que sua poesia é um permanente esforço por compreender a própria poesia, que em sua obra o fazer poético se apresenta como fazer teológico, como expressão da experiência de um sagrado independente de qualquer tradição religiosa.

\section{Teopoética do traste feita ao rés do chão}

Anteriormente trouxemos um dos poemas mais expressivos no que diz respeito a essa questão: Teologia do traste (Cf. BARROS, 2010, p. 438). Este poema é emblemático por dois motivos, primeiro; porque traz um dos temas fundamentais que percorre toda obra de Manoel de Barros que é o ordinário, ou seja, como nas próprias palavras do autor: "Tudo aquilo que nossa civilização rejeita, pisa e mija em cima” (BARROS, 2010, p. 146); segundo, o poema se propõe ser, como o paratexto já indica, uma fala sobre o divino: Teologia do traste. Mas não é qualquer teologia, é uma teologia do traste, do imprestável, das latas enferrujadas, do nulo, do nada. Aqui é que está o ponto nevrálgico da compreensão do sagrado que emerge da poesia manoelina: O Deus de Manoel de Barros se encontra no chão, nos vermes, nos trastes, nos loucos, no cisco, no catre, no ordinário. As imagens elencadas são, como veremos adiante, imagens que o poeta utilizou para apontar a manifestação do sagrado entre nós. O olhar da poesia de Manoel de Barros é subversivo, pois sua íris só consegue contemplar o divino nas coisas sujas: "Queria que os vermes iluminassem" (BARROS, 2010, p. 438). 
Este olhar singular para as coisas ordinárias já está presente desde a sua primeira obra, Poemas concebidos sem pecado (1937), em que o poeta destina os poemas do último capítulo do livro, intitulado de "Retratos a carvão", a personagens marginais de sua cidade, são prostitutas: "Antonhinha-me-leva", mendigos: "Raphael", negros: "Polina", loucos: "Raphael". Do último poema, retiramos um fragmento em que o poeta já demonstra sua consciência e predileção pelos marginalizados, pelo que não é sublime, pelos desimportantes:

\author{
Nem toco harpas. \\ Só uma viola quebrada \\ Surda como uma porta \\ Mais nada. \\ De resto \\ Juvêncio não é um herói \\ Raphael não tem mãe \\ E nenhuma cidade disputará a glória de me haver \\ dado a luz. \\ Falo da vida de um menino do mato sem importância. \\ Isto não tem importância. \\ (BARROS, 2010, p. 29)
}

A predileção pelo traste que se acentuará ao longo de sua obra, já se apresenta, ainda que embrionária, nos versos primevos de Manoel de Barros. O poema evoca imagens do abandono e do imprestável: "Nem toco harpas, só uma viola quebrada". Aqui, o sublime, que é representado pelo vocábulo harpa, é suprimido pela viola quebrada, que nos remete ao que é inútil, ao desimportante. Mais evocativo ainda, neste poema, é a referência explícita de que seu personagem não é um herói, e sim um homem anônimo, do povo: "Juvêncio não é um herói", arrematando o feixe do poema com o verso: "Falo da vida de um menino do mato sem importância/ Isto não tem importância”.

A vida anônima, do chão, do mato será um dos temas mais recorrentes na produção manoelina, ligado a isto estará o olhar peculiar que a obra debruça sobre o que é ordinário. No entanto, este olhar sobre o traste, apresenta uma ótica diferenciada, pois não se vê o traste apenas como traste, mas a partir do traste se chega ao sublime, ou melhor, o traste é a via por excelência para o sublime na poesia de Manoel de Barros, este é o grande paradoxo que sua obra sustenta. 
A grande matéria da poesia manoelina será mesmo os despojos humanos, incluindo o próprio homem, aqueles que, assim como as fezes, são considerados como dejetos pela sociedade do sublime e do higienizado: os loucos, os sem-teto, as prostitutas, os andarilhos; as coisas desimportantes: latas, sucatas; a língua inculta que o autor, metaforicamente, chamou de: desperdícios verbais. Toda essa gama de referências ao traste já se faz presente em sua obra primeira, assim como o poeta apontou em sua fala. Sua poesia está voltada para o mundo, não para o sideral, o celeste, o sublime, sua matéria é a pessoa humana.

Desde Poemas concebidos sem pecados (1937) até Menino do mato (2010), seu último livro de poesias publicado, observamos a referência a imagens do ordinário como lugar onde o sublime se faz presente. No poema sem título de número 34, da obra Menino do Mato, o autor reafirma, mais uma vez, a eleição das coisas ordinárias como matéria de sua poesia:

Ele sabia que as coisas inúteis e os homens inúteis se guardam no abandono.

Os homens no seu próprio abandono.

$\mathrm{E}$ as coisas inúteis ficam pra poesia.

(BARROS, 2010, p. 465)

A estudiosa de sua obra, Cristina Campos, em sua obra Manoel de Barros: $\mathrm{O}$ demiurgo das terras encharcadas - educação pela vivência do chão, afirma que: "Uma das características que singularizam a obra de Manoel de Barros é a eleição das coisas pequenas do chão - coisas ordinárias - como matéria de poesia" (CAMPOS, 2010, p. 180). Partindo desta afirmação buscamos verificar esta recorrência temática, que fora confirmada à medida que fomos avançando na leitura de seus poemas, e que se mostrou para nós como uns dos pontos principais de nossa análise da obra poética manoelina.

O tema do traste torna-se a marca registrada de uma poesia singular no quadro da literatura brasileira, rompendo com a visão de que a poesia está voltada para as coisas sublimes, provocando uma inversão de valores estéticos e incitando uma crítica à sociedade capitalista. O crítico Marcelo Marinho nos remete a este traço característico da obra de Barros quando diz que: 
A matéria pré-concebida de forma trivial e inútil (segundo o juízo das pessoas alheias às pequenas coisas do universo) passa a ser exaltada por ocupar o mais alto degrau da hierarquia poética. Paulatinamente, torna-se perceptível a abertura de uma nova visão de mundo, uma cosmovisão notada a partir das coisas ínfimas do chão (MARINHO, 2009, p. 54).

A construção de uma lírica do traste arremessa-nos a uma experiência com o rasteiro, com o chão, com as coisas pérfidas e nulas da existência humana. Com o que existe de mais banal e desimportante no nosso cotidiano imediato. Não há, para Manoel, grandeza humana se ela não passar pelo baixo. No baixo está a incubadora que nos gera e o leito último que nos acolhe no "fim”. Há, paradoxalmente, uma exuberância no ínfimo. Paradoxo em um primeiro olhar, porque para Manoel não há contrários, pois: “As antíteses congraçam” (BARROS, 2008, p. 49). Importante não são as galáxias, mas o mundo debaixo das pedras onde nascem os musgos. Para o poeta não há coisas simples. É ingênua a ideia de que a natureza é expressão apenas da simplicidade, da "beleza", do sublime, pois o feio e o monstruoso também fazem parte do mundo natural, tanto quanto do mundo humano. Em Manoel se elege as coisas consideradas menores, ou sem valor, é para elevá-las, sem sair do chão, à categoria do sublime, do celeste.

A matéria de que se constitui a poética de Manoel de Barros é feita de excrementos, dejetos, seres dispostos à ferrugem, inutensílios, trastes, tudo que é desimportante; como afirma o próprio poeta em entrevista concedida a José Octávio Guizzo, em 1970, para a Revista Grifo (Campo Grande, MS) e que Adalberto Muller republicou em 2010, na série Conversas, da Azougue Editorial:

A matéria de minha poesia são "os nervos do entulho", como disse o poeta português José Gomes Ferreira. Tudo aquilo que nossa civilização rejeita, pisa e mija em cima, é também matéria de minha poesia, eu já disse. Só bato continência para árvore, pedra, cisco. $\mathrm{O}$ cisco semovente e o propriamente cisco. (...) De muita compaixão é feita a poesia de nosso século. Um fundo amor pelos humilhados e ofendidos de nossa sociedade banha quase toda a poesia de hoje. Esse vício de amar as coisas jogadas fora - eis minha competência. É por isso que eu sempre rogo pra minha Nossa Senhora da Minha Escuridão que me perdoe por gostar dos desheróis. Amém. (MÜLLER, 2010, p. 45). 
Percebe-se aqui uma profunda adesão ao que é rasteiro. A voz do poeta, por meio de seu testemunho e sua crítica, é confirmada também em sua poesia, reforçando o caráter obsessivo que tem Manoel de Barros pelo marginal, pelo que é segregado por nossa sociedade do luxo, do consumo, do artificial e higienizado: "O que é bom para o lixo é bom para poesia" (BARROS, 2010, 147), afirma Manoel em seu poema Matéria de Poesia. A poesia manoelina é bruta, natural, excrementícia. Nela o homem está desvelado de qualquer subterfúgio que negue sua natureza primeva: barro, suor, veias, pelos. O baixo é o lugar onde habita a poesia de Manoel de Barros. Não há sobrevoos para as nuvens, o céu é visto no espelho das águas, na íris de uma garça. Nunca se sai do chão, o céu já habita o chão.

A poesia de Manoel de Barros é um rico manancial das experiências corporais do homem com o chão:

Aprendo com abelhas do que com aeroplanos.

É um olhar para baixo que eu nasci tendo.

É um olhar para o ser menor, para o insignificante que eu me criei tendo.

O ser que na sociedade é chutado como uma barata - cresce de importância para meu olho.

Ainda não entendi por que herdei esse olhar para baixo.

Sempre imagino que venha de ancestralidades machucadas.

Fui criado no mato e aprendi a gostar das coisinhas do chão -

Antes que das coisas celestiais.

Pessoas pertencidas de abandono me comovem: tanto quanto as soberbas coisas ínfimas.

(BARROS, 2010, p. 361)

O chão é elevado à categoria de poético. O olhar direciona-se para a terra. O poeta afirma sua predileção pelas coisas rasteiras, sua preocupação está voltada para os seres marginalizados, para as "pessoas pertencidas de abandono". Este poema é emblemático na poética de Manoel de Barros, pois nele vemos uma espécie de confissão pública do seu amor pelas "coisinhas do chão". O rebaixamento constitui o movimento que impulsiona sua criação, como diz Bakhtin: "o rebaixamento, isto é, a transferência ao plano material e corporal, o da terra e do corpo na sua indissolúvel unidade, de tudo que é elevado, espiritual, ideal e abstrato" (BAKHTIN, 2008, p. 17). Esta dissociação entre celeste e terreno é também 
evocada claramente por Manoel: "Fui criado no mato e aprendi a gostar das coisinhas do chão - antes que das coisas celestiais". O poeta elege as coisas concretas do chão em detrimento ao abstrato e celestial, tão presentes na tradição literária.

O olhar para o chão da poesia de Manoel de Barros deixa entrever uma singular visão relativa ao sagrado, desprendida de toda solenidade, nobreza e abstração. Seu deus se faz presente no simples, no pobre e enraizado na terra. Diferentemente de grande parte da tradição cristã que se voltou para as coisas do alto e se esqueceu da encarnação do verbo na materialidade humana. Diante deste transcendentalismo que predominou sobre a cultura cristã, Manoel de Barros expressa que sua poesia intenta estabelecer um novo paradigma diante da mensagem cristã, vejamos o que nos fala o poeta:

Penso que trago em mim uma pobreza ancestral que me eleva para as coisas rasteiras. Disse uma vez: "só as coisas rasteiras me celestam". Procede que a pobreza é bíblica, procede que o ordinário é sagrado - e a desgrandeza é de Deus. Com o canto do sol e das aves nosso Francisco fertilizava sua fé. Agora, descomparando: quero fertilizar os meus cantos com as pobres coisas do chão. Sendo que não sou eu que cristianizo as ordinariedades, mas a minha linguagem (MULLER, 2010,p. 103).

A voz do poeta traz questões basilares que estão presentes em sua poesia. Primeiramente é importante notar o lugar em que o poeta se coloca, autoafirmando sua pobreza e seu pertencimento às coisas rasteiras. Segundo, desloca o sagrado do espaço do sublime, do superior e do extraordinário e aloca a experiência do divino no seio do ordinário, mais ainda, compreende o traste como o próprio sagrado e as coisas pequenas e anônimas como qualidades de Deus: "a desgrandeza é de Deus". E, por fim, assemelha sua poesia à postura que teve Francisco de Assis, o santo italiano do Século XIII, ao compor um cântico em louvor as pobres coisas da terra. Este olhar que mira para baixo em busca das coisas celestiais que habitam o chão se torna a marca caracterizadora que a poesia de Manoel de Barros estabelece com o sagrado, o sagrado está ao rés do chão. A poesia manoelina ultrapassa a ideia, nos moldes agostinianos, de uma cidade celestial que estaria para além da história e do mundo, pelo contrário, sua poesia intenta superar esta distinção entre céu e terra, pois o celeste se encarna no terreno.

Elton Luiz Leite de Souza, ao analisar a obra do poeta afirmou que na poética manoelina: “entre o ordinário e o extraordinário não existe uma diferença intransponível: é no 
seio do ordinário que o extraordinário acontece" (SOUZA, 2010, p. 74). Baixo e Alto não existem em Manoel como coisas díspares, pois sua poesia não se erige levando em conta estas polaridades. Diz o poeta "é no ínfimo que vejo a exuberância" (BARROS, 2008, p. 55), o céu já habita o chão e só as coisas terrenas divinam.

Neste momento recuperamos a compreensão de Octavio Paz (2016) quando entende o problema da transcendência com um olhar encarnado na imanência. Não existe para Paz uma vida celestial que não passe pela matéria, o lugar onde o divino se manifesta é o mundo, ou seja, é do chão que vejo o céu. Só a partir das coisas rasteiras chego às coisas celestes. Em seu Livro sobre Nada (1996), Manoel de Barros tece uma poética que vislumbra o sagrado através do chão, ou seja, toda experiência do divino parte da imanência das coisas ordinárias, sem préstimo, enraizadas na cotidianidade e arremessadas ao chão:

Prefiro máquinas que servem para não funcionar: quando cheias de areia de formiga e musgo - elas podem um dia milagrar de flores.

(Os objetos sem função têm muito apego pelo abandono)

Também as latrinas desprezadas que servem para ter Grilos dentro - elas podem um dia milagrar violetas.

(Eu sou beato em violetas)

Todas as coisas apropriadas ao abandono me religam

a Deus.

Senhor, eu tenho orgulho do imprestável!

(O abandono me protege)

(BARROS, 2010, p. 342)

Os versos do poema monoelino erigem através da emissão lírica uma visão teológica que inverte paradigmas e valores entendidos, tradicionalmente, como teológicos. Primeiro, enuncia-se a predileção pelo que é inútil: "prefiro maquinas que servem para não funcionar", um paradoxo que nos desconcerta, pois a postura utilitarista do homem acostumado apenas a considerar relevante aquilo que lhe é útil, quebra-se com a antítese do verso. Aquilo que é inútil e comumente desprezado, aquilo que é apenas casa de musgos e de terra de formiga torna-se o lugar onde o maravilhoso acontece: "elas podem milagrar flores". O lugar do 
sagrado, a despeito das tradições religiosas, não é a igreja, a sinagoga, a mesquita, mas: "latrinas desprezadas que servem para ter grilos dentro", lugar onde milagram violetas. É uma inversão total que a poesia de Manoel de Barros opera, vendo na dispersão das "coisas jogadas foras por motivo de traste"(BARROS, 2010, p. 147) o habitat do divino. Só através deste contato com as coisas abandonadas e ligadas ao chão, é que o poeta se encontra com Deus: "Todas as coisas apropriadas ao abandono me religam a Deus", ou seja, a experiência religiosa de Manoel de Barros se dá através do contato com as coisas desprezadas, é no abandono que Deus habita.

Essa busca que intenta elevar as coisas rasteiras à categoria de poética e divina é caracterizadora da verdadeira poesia, na visão de Octavio Paz, se negava considerar o conteúdo da poesia apenas com temas heroicos, tidos como importantes ou superiores: “A verdadeira vida não se contrapõe à vida cotidiana nem à heroica; é a percepção do cintilar da outridade em qualquer de nossos atos, sem excluir os mais mínimos" (PAZ, 2012, p. 272). A poesia de Manoel de Barros é exemplar neste aspecto, pois o maravilhoso habita o ordinário. A vida simples, corriqueira, os atos e exercícios cotidianos se apresentam como manifestação da divindade. A poesia se configura, então, como a forma que dá enlevo ao banal, ao simples e despercebido. Ao debruçar o olhar sobre as coisas humílimas, a poesia de barros monumenta o pequeno:

Venho de nobres que empobreceram.

Restou-me por fortuna a soberbia.

Com esta doença de grandezas:

Hei de monumentar os insetos!

(Cristo monumentou a Humildade quando beijou os

pés dos discípulos.

São Francisco monumentou as aves.

Vieira, os peixes.

Shakespeare,o Amor, a Dúvida, os tolos.

Charles Chaplin monumentou os vagabundos.)

Com esta mania de grandeza:

Hei de monumentar as pobres coisas do chão mijadas de orvalho.

(BARROS, 2010, p. 343)

O eu-poético apresenta-se como um nobre decadente, e de sua riqueza restou o gosto de elevar as coisas, esta "doença de grandezas". No entanto, a sua índole nobre é subversiva, 
seu desejo, contrariamente ao senso comum que costuma elevar o que é sublime, seu desejo é “monumentar os insetos". É um paradoxo que se estabelece, como se monumenta o que é baixo e pequeno? Olhar subversivo da poética manoelina reside neste aspecto, na postura de trazer para espaço nobre da poesia aquilo que é ralo, baixo e pobre. Apresenta-se nos versos do poema a estirpe à qual o poeta pertence: Cristo, que monumentou a humildade através do ato de lavar os pés dos discípulos na última ceia, momento em que o poeta estabelece uma relação interdiscursiva e intertextual com a bíblia, recuperando o texto evangélico; São Francisco de Assis, o santo que pregou para os pássaros, motivo pelo qual o eu-poético afirma que "monumentou as aves"; Padre Antonio Vieira, que no poema faz-se referência ao Sermão de Santo Antonio aos peixes, em que o jesuíta português usou alegoricamente os peixes para enaltecer a virtude humana da humilde contra à luxúria e riqueza; Shakespeare, que mesmo elegendo personagens nobres, no fundo, exaltou, segundo a ótica de Barros, os sentimentos e paixões humanas; e por fim Charles Chaplin, arquétipo do homem comum e banal, que com sua vagabundagem conseguiu instituir uma critica contra à maquina capitalista. As imagens elencadas ao longo do poema demarca a linhagem literária a qual o poeta filia-se, e ainda demarca o lugar nesta tradição, a tradição que escolheu o simples e banal como matéria de sua poesia: animais, vagabundos, vícios e virtudes. Sua postura poética seria a de: "monumentar as pobres coisas do chão mijadas de orvalho", buscando revelar o maravilhoso que habita o mundo das coisas rasteiras. A imagem que o verso evoca com o paralelo mijo/orvalho atribui aspecto de sublime ao que é abjeto. E a poesia tem esse poder, o de, segundo Octavio Paz, revelar a maravilha e o divino pousado na cotidianidade da vida: "Uma das funções centrais da poesia é mostrar-nos o outro lado das coisas, o maravilhoso cotidiano: não a irrealidade, mas a prodigiosa realidade do mundo" (2013, p. 59). Dizer isto implica considerar que a poesia, ao derramar seu olhar sobre as coisas cotidianas revela, paradoxalmente, seu extraordinário.

No poema de título muito sugestivo, Bênçãos, o eu-poético reconhece Deus na imediatez do mundo, no voo da garça, nos tons do azul, na transcendência que habita o chão, e por isso mesmo, imanência:

Não tenho a anatomia de uma garça para receber em mim os perfumes do azul.

Mas eu recebo. 


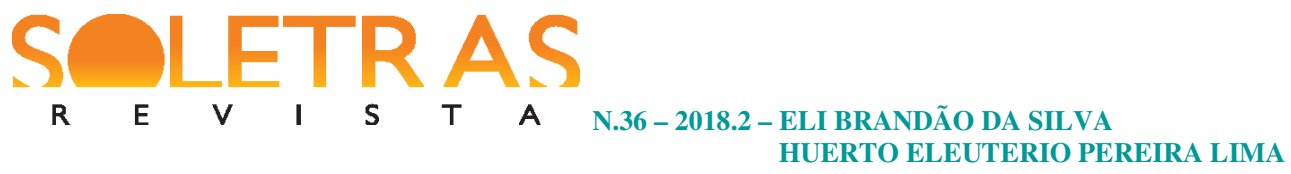

É uma benção.

Às vezes se tenho uma tristeza, as andorinhas me namoram mais de perto.

Fico enamorado.

É uma benção.

Logo dou aos caracóis ornamentos de ouro para que se tornem peregrinos do chão.

Eles se tornam.

É uma benção.

Até alguém já chegou de me ver passar

a mão nos cabelos de Deus!

Eu só queria agradecer.

(BARROS, 2010, p. 479)

A expressão do discurso sobre o sagrado configurada a partir do chão na poesia de Manoel de Barros é um aspecto que torna esta produção literária uma singular (re)criadora de expressões teológicas, e caracterizam o fazer teopoético de Manoel de Barros.

Nesta nossa teopoética empreendemos uma hermenêutica da obra manoelina com apoio de elementos interdiscursivos, tendo em vista ressaltar que o discurso teológico na obra do poeta se processa com expressão de uma experiência religiosa e se constrói a partir do traste, ao rés do chão.

\section{Referências}

BAKHTIN, Mikhail. A cultura popular na Idade Média e no Renascimento: o contexto de François Rabelais. Trad. de Yara Franteschi Vieira. São Paulo: Hucitec; Brasília: Editora Universidade de Brasília, 2008.

BARROS, Manoel de Barros. Poesia completa. São Paulo: Leya, 2010.

BÍBLIA SAGRADA. Trad. Ivo Storniolo. São Paulo: Paulus, 1990.

BÍBLIA DE JERUSALÉM. São Paulo: Paulus Editora, 2013.

BRANDÃO, Eli. Jesus-Severino e a teimosa esperança. In: Estudos de religião, 32, São Bernardo do Campo, SP, UMESP, 2007.

BRANDÃO, Eli. Literatura e religião tecidas na metáfora. Plural Pluriel, v. 15, 2016. Disponível em: http://www.pluralpluriel.org/index.php/revue/article/view/50.

CALASSO, Roberto. A literatura e os deuses. Trad. Jônatas Batista Neto. São Paulo: Companhia das Letras, 2004. 
CAMPOS, Cristina. Manoel de Barros: o demiurgo das terras encharcadas. Educação pela vivência do chão. Cuiabá: Carlini \& Caniato, 2010.

CARPINEJAR, Fabrício. Teologia do traste: a poesia do excesso de Manoel de Barros. Dissertação de Mestrado. Universidade Federal do Rio Grande do Sul, 2001.

ELIADE, Mircea. O sagrado e o profano: a essência das religiões. Trad. Rogério Fernandes. São Paulo: Martins Fontes, 2008.

FIORIN, José Luiz. Polifonia textual e discursiva. In: BARROS, Diana Luz Pessoa de; FIORIN, José Luiz (Orgs.). Dialogismo, polifonia, intertextualidade. São Paulo: EDUSP, 1999, p. 29-36.

MAINGUENEAU, Dominique. Gênese dos discursos. Curitiba: Criar Edições LTDA, 2007.

. Novas tendências em Análise do Discurso. Campinas, SP: Editora da Universidade Estadual de Campinas, 1993.

MAGALHÃES, Antonio Carlos de Melo. Expressões do sagrado: reflexões sobre o fenômeno religioso. Aparecida, SP: Editora Santuário, 2008.

2000.

Deus no espelho das palavras: teologia e literatura em diálogo. São Paulo: Paulinas,

MARINHO, Marcelo. Manoel de Barros: O brejo e o solfejo. Campo Grande: Letra Livre, 2009.

MULLER, Adalberto. Manoel de Barros: Encontros. Rio de Janeiro: Beco do Azougue, 2010.

PAGÁN, Luis N. Rivera. Teologia, Literatura e Identidad Cultural em América Latina y el Caribe. In: Sociopoética, v. 1, n. 8, jul.-dez. 2011, p. 119-138.

PAZ, Octavio. O arco e a lira. Trad. Ari Roitman e Paulina Wacht. São Paulo: Cosac Naify, 2012.

2013.

Os filhos do barro. Trad. Ari Roitman; Paulina Wacht. São Paulo: Cosac Naify,

SOUZA, Elton Luiz Leite de. Manoel de Barros: a poética do deslimite. Rio de Janeiro: 7letras, 2010.

\section{Theopoetics of the fret of Manoel de Barros}

Abstract: This article presents a theopoetic reading of the work of the poet Manoel de Barros, analyzing and interpreting his poetry as (re) theological creation. It is assumed that his poems configure in a single tissue complex relations between literature and religion, poetry and 


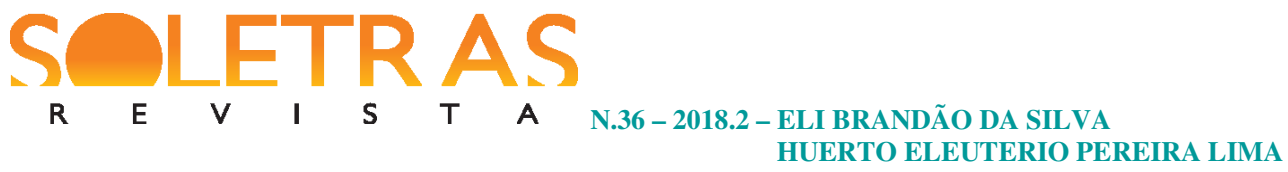

theology, poetry and sacred. The understanding is that in the poetry of Manoel de Barros the sacred is associated with "things thrown away by reason of fret", on the ground, and that the ordinary things of daily life as well as excluded people are expressions through which the divinity is named and manifested. It is a singular poetry that weaves a poetic saying that returns the look to the humiliated things, monuments the small, sacralizes the ground and combines poetic experience with religious experience. The interpretation of figures and themes concerning the relations between the human and the sacred in the work of the poet is operated through an interdiscursive hermeneutics, which is based on theological and literary knowledge. In this theopoetic venture, the contributions of Pagan (2011), Paz (2012/2013), Magalhães (2013), Fiorin (1999), Maingueneau (2007), and others.

Keywords: Poetry. Theology. Manoel de Barros.

Recebido em: 20 de abril de 2018.

Aceito em: 23 de junho de 2018. 